\title{
Experiences of international medical students enrolled in Chinese medical institutions towards online teaching during the COVID-19 pandemic
}

\author{
Sarfraz Aslam ${ }^{\text {Corresp., } 1}$, Huma Akram ${ }^{2}$, Atif Saleem ${ }^{3}$, BaoHui Zhang ${ }^{\text {Corresp. } 1}$ \\ ${ }^{1}$ School of Education, Shaanxi Normal University, Xian, Shaanxi, China \\ 2 Faculty of Education, Northeast Normal University, Changchun, Jilin, China \\ 3 College of Teacher Education; College of Education and Human Development, Zhejiang Normal University, Jinhua, Zhejiang, China \\ Corresponding Authors: Sarfraz Aslam, BaoHui Zhang \\ Email address: sarfrazmian@nenu.edu.cn, baohui.zhang@snnu.edu.cn
}

Introduction. The COVID-19 pandemic has forced the world to pause. One hundred and eighty-eight countries have imposed countrywide school closures, affecting more than 1.5 billion children and youths. The majority of academic leaders are currently encouraging online education to resolve this crisis. This study aimed to investigate international medical students' (IMS) experiences of online teaching during the COVID-19 pandemic.

Methods. Data were collected online using a validated questionnaire and one open-ended question, presented on the Google forms platform. The study attracted responses from 1107 IMS volunteer participants. IBM SPSS v. 25, GraphPad Prism v. 9, and MindManager v. 2018 were used for data analysis. All variables were subjected to descriptive statistical analysis. The Mann-Whitney $U$ test was used in subgroup analysis and the Kruskal-Wallis test was also applied for year-wise comparisons. Open-ended text responses were analyzed qualitatively, extracting themes by which responses were classified.

Results. Among 1107 respondents, a total of $67.8 \%$ were males, and the majority (63.1\%) of the IMS were in the age group of 21-23 years. The results show that more than half of the respondents reported their Internet connection quality as poor to average. Poor Internet connection severely affected IMS online learning experience. Persistent and recurrent issues with Internet access became a significant concern for IMS. Lack of electricity is one of the factors that can contribute to poor learning output and dissatisfaction with online teaching. IMS perceive online medical education as unhelpful in several phases of the training, such as improving their clinical skills, knowledge, and discussion skills.

Conclusions. During these unprecedented periods, online teaching has allowed medical education to continue. However, IMS are generally dissatisfied with online teaching. Medical students must visualize the human body, so supportive technologies are important to compensate for the lack of clinical practices. Medical institutions may need to invest in faculty training programs and continually adjust to enhance the content of online training and international partnerships. A switch from conventional face-toface teaching to a fully functional virtual education framework in the medical education field will take time and experience.

Keywords: Medical students, Medical Education, COVID-19, Online teaching, China, Pandemic, International students. 


\section{Experiences of international medical students}

2 enrolled in Chinese medical institutions towards

3 online teaching during the COVID-19 pandemic

4

5

6

7

8

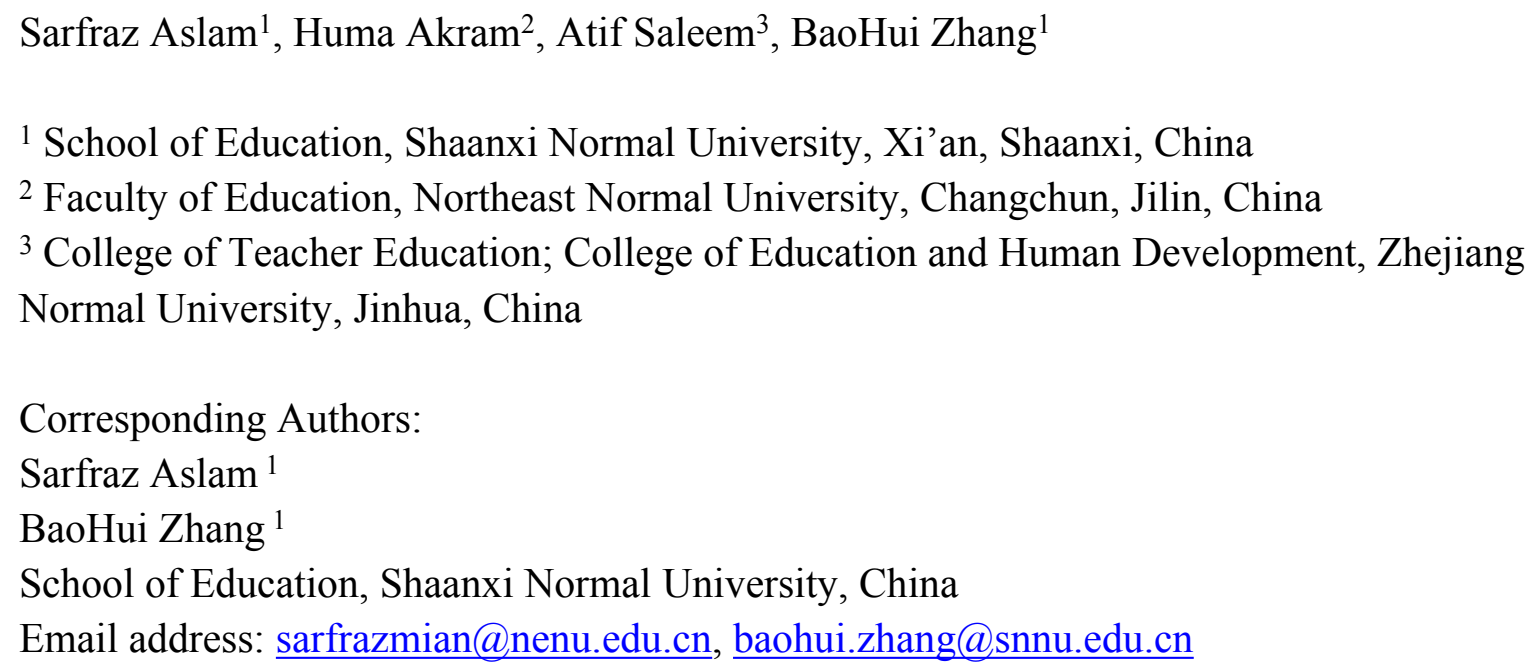

\section{Abstract}

Introduction. The COVID-19 pandemic has forced the world to pause. One hundred and eightyeight countries have imposed countrywide school closures, affecting more than 1.5 billion children and youths. The majority of academic leaders are currently encouraging online education to resolve this crisis. This study aimed to investigate international medical students' (IMS) experiences of online teaching during the COVID-19 pandemic.

Methods. Data were collected online using a validated questionnaire and one open-ended question, presented on the Google forms platform. The study attracted responses from 1107 IMS volunteer participants. IBM SPSS v. 25, GraphPad Prism v. 9, and MindManager v. 2018 were used for data analysis. All variables were subjected to descriptive statistical analysis. The MannWhitney $U$ test was used in subgroup analysis and the Kruskal-Wallis test was also applied for year-wise comparisons. Open-ended text responses were analyzed qualitatively, extracting themes by which responses were classified.

Results. Among 1107 respondents, a total of $67.8 \%$ were males, and the majority (63.1\%) of the IMS were in the age group of 21-23 years. The results show that more than half of the respondents reported their Internet connection quality as poor to average. Poor Internet connection severely affected IMS online learning experience. Persistent and recurrent issues with Internet access became a significant concern for IMS. Lack of electricity is one of the factors that can contribute to poor learning output and dissatisfaction with online teaching. IMS perceive online medical education as unhelpful in several phases of the training, such as improving their clinical skills, knowledge and discussion skills. 
40 Conclusions. During these unprecedented periods, online teaching has allowed medical

41 education to continue. However, IMS are generally dissatisfied with online teaching. Medical

42 students must visualize the human body, so supportive technologies are important to compensate

43 for the lack of clinical practices. Medical institutions may need to invest in faculty training

44 programs and continually adjust to enhance the content of online training and international

45 partnerships. A switch from conventional face-to-face teaching to a fully functional virtual

46 education framework in the medical education field will take time and experience.

47 Keywords: Medical students, Medical Education, COVID-19, Online teaching, China,

48 Pandemic, International students

49

50

51

52

53

\section{Introduction}

\section{Current scenario: the world and China}

The twenty-first century is experiencing what may be one of its most devastating events. Now known to the world as the COVID-19 pandemic, the virus swiftly engulfed the whole world with almost 11 million cases in a span of around six months. It has not only increased the global burden of disease but has heavily dented many social systems, including education (Baloch et al., 2021). The World Health Organization (WHO) announced the COVID-19 outbreak initially as a public health emergency of international concern on January 30, 2020 and later declared it a pandemic on March 11, 2020 (WHO, 2020). In China, the first case of novel coronavirus was reported in Wuhan in December 2019 (Chen et al., 2020; Huang et al., 2020). At that time it was not expected to become a pandemic, but by June 20th 2020 COVID-19 had infected more than 8.5 million and killed 460 thousand people globally (Sindiani et al., 2020).

Soon after this viral outbreak, semester break was approaching in China and many international students were returning to their homes for vacations. The Chinese Ministry of Foreign Affairs announced that all students (local and international) must await official permission before returning to their institutions (S. Wang \& Dai, 2020). On $28^{\text {th }}$ March 2020, in view of the rapid global spread of COVID-19, China temporarily suspended the right of foreign nationals holding valid visas or residence permits, including international students, to enter the country (Overseas Security Advisory Council, 2020).

With the growing influence of Chinese education, the number of students in China is increasing (Gu et al., 2020). In 2017, China became the leading destination for international students in Asia (Jianfeng, 2018). China is currently one of the fastest-growing destinations for international medical students (IMS) (Fan et al., 2013), having received over 68,000 IMS, mostly from Asian and African nations (G. X. Li, 2019). More than 10,000 students came to China to study medicine in 2018, most of whom chose a Bachelor of Medicine Bachelor of Surgery (MBBS) program delivered in English. Chinese medical institutions offer an English-taught 6-year undergraduate program (MBBS) that includes 5-year theoretical and practical studies courses and a one-year clinical rotation internship. Successful students receive a bachelor's degree in medicine and surgery at the end of the program. The Chinese government has authorized 49 medical institutions to accept IMS (Chu et al., 2019). Each of those students requires a study visa 
80

81

82

83

84

85

86

87

88

89

90

91

92

93

94

95

96

97

98

99

100

101

102

103

104

105

106

107

108

109

110

111

112

113

114

115

116

117

118

119

and many of those planning to work in China after graduation are required to apply for a work visa (W. Li \& Sun, 2019).

The COVID-19 pandemic has forced the world to pause, and countries worldwide have implemented strict policies to avoid disease transmission (Sarwar et al., 2020). It was observed by UNESCO (2020) that $91 \%$ of the total global student population has been absent from school in more than 188 countries affected by the pandemic (Koçoglu \& Tekdal, 2020).

\section{COVID-19 and online medical education}

In order to continue to offer higher education, authorities worldwide issued new recommendations on conversion to online university teaching and most academic leaders are currently encouraging this switch (UNESCO, 2020). In the COVID-19 pandemic situation, universities at all levels worldwide have led their teachers and students to use material conventionally delivered face to face via an online format.

Accelerated development of IT systems and enhancement of Internet mechanisms have allowed online learning to become central to modern global education (K. Wang et al., 2020). Moving from on-campus to distance learning may be facilitated by methods such as self-paced independent study and remote interactive workshops, or real-time immersive settings that are needed for distance learning (Cook et al., 2010).

A rise in external resources and teaching programs such as Osmosis and BiteMedicine has allowed many teaching sessions to be available to medical students online (Dost et al., 2020). Learning health and medicine with Osmosis is intended to be fun, with a visual style to help communicate difficult concepts by grounding them with visual memory anchors, memorable characters, and engaging animations (Osmosis, n.d.), and BiteMedicine is a free complete resource intended to help medical students excel in their medical studies. Question banks, online textbooks, live webinars and forums are provided to help students to pass their exams (BiteMedicine, n.d.).

Several studies indicate that online and blended educational approaches are equivalent to conventional classroom models. However, few studies are based on students and teachers' satisfaction with online education during situations such as the COVID-19 pandemic (Muflih et al., 2020). Appraising a student's simulated learning experience may help assess the effectiveness of an online training program (Hamutoglu et al., 2020).

\section{Medical students' perceptions about online learning}

The online learning experiences of medical students globally have been the focus of many recent studies. A national cross-sectional survey (Dost et al., 2020) investigated 2721 UK medical students' perceptions of online teaching during the COVID-19 pandemic. It was concluded that online teaching had allowed the continuity of medical education during these exceptional times. A cross-sectional survey among medical students in the North of Jordan (Sindiani et al., 2020) found that most medical students favored the conventional face-to-face teaching method over the solo online teaching methods. 
120

121

122

123

124

125

126

127

128

129

130

131

132

133

134

135

136

137

138

139

140

141

142

143

144

145

146

147

148

149

150

151

152

153

154

155

156

157

158

A survey of Pakistani dentistry graduates found that they were unanimously unhappy with different online teaching sessions (Sarwar et al., 2020). However, a nationwide survey of online teaching strategies in dental education in China found the online delivery to be necessary and effective during the outbreak. The study recommends that the online education model and pedagogy may be enhanced for future delivery of dental education (K. Wang et al., 2020). As mentioned earlier, China is host to many IMS, but to date no study has investigated their online learning experiences. Research on this issue is important as a basis for development of sophisticated online learning-enabled programs. The present study therefore aimed to:

1. Assess the experiences of IMS regarding the effectiveness of online teaching.

2. Investigate the challenges faced by IMS in adjusting to this new mode of learning.

3. Propose practical strategies for medical institutions to address the identified factors. The findings of this research will serve as the foundation for future applied and intervention studies, as a guide for universities and policymakers worldwide, and may be used to better understand the positive role of online teaching in medical education.

\section{Materials and Methods}

A cross-sectional survey design was used for data collection (Fraenkel et al., 1993) between January and March 2021 via an online Google-based questionnaire.

\section{Participants}

The target population was IMS studying in various medical institutions in China. Undergraduate IMS who were enrolled and took online courses from the first to the fifth year in the 6-year MBBS program were included in this study. A total of 1107 IMS from fifteen medical institutions across China were recruited by simple random sampling in which each member of the population has an equal chance of being selected. This approach removes bias from the selection procedure and should result in a representative sample (Gravetter \& Forzano, 2011). Ideally, a sample size of more than a few hundred is required in order to apply this sampling technique (Saunders et al., 2009). The present study sample size was determined using an OpenEpi online calculator. If $50 \%$ of the target population subjects were interested in participating, a sample size of 385 would be required to assess the estimated proportion at $5 \%$ absolute precision and $95 \%$ confidence (Dhand \& Khatkar, 2014). Moreover, a sample size of about 400 should be sufficient for a large population (Krejcie \& Morgan, 1970). The G*Power 3.1 calculator was used to compute statistical power of 0.95 , above the value of 0.80 considered adequate in social science research (Hair Jr et al., 2016; Uttley, 2019).

\section{Instrument}

The data collection tool consisted of two parts: a questionnaire and an open-ended question.

\section{Questionnaire}


159 A validated questionnaire (Sarwar et al., 2020) in English consisting of 31 items (without sub160 dimensions or inverse items), with a mixture of question styles including 5-point Likert-type 161 questions, was used to collect the data (File S1). The questionnaire is considered highly reliable, 162 the Cronbach's alpha value of the original version being 0.78 (Sarwar et al., 2020). The current 163 authors checked validation prior to the final data collection and found Cronbach's alpha value of 1640.83 indicating an acceptable level of internal consistency. This questionnaire was designed and 165 used to measure the self-reported effectiveness of medical e-learning classes during the COVID16619 pandemic. The questionnaire explored the following three themes (1) Demographics of 167 participants (2) General information about technology readiness and online classes (3)

168 Effectiveness of online classes.

169

170

\section{Opinions about online teaching}

171 The current researchers added one open-ended question asking "Please tell us the three most

172 crucial improvements required to make online sessions more effective and anything you want to 173 share; please feel free to share" intended to gather IMS perspectives about the challenges they

174 face during online teaching and their suggestions for improvements to make online sessions 175 more effective.

176

\section{Ethical considerations and Participation}

179

180

181

182

183

184

185

186

187

188

189

190

191

192

193

194

195

196

197

198

Ethics committee approval was received from Shaanxi Normal University's institutional review board (reference number AR 2021-01-001). IMS were given brief information about the study and were invited to agree to participate using the consent form on the first page of the online questionnaire. Participation was voluntary, and before beginning the survey, participants were told that all data obtained would be anonymous and would be used for research purposes only. At the start of the survey, a mandatory email id was required to validate participation, affirming consent and preventing multiple responses.

\section{Data Collection}

The survey was created using Google forms, and the link was distributed to IMS globally via social media (WeChat, WhatsApp, Facebook and others). The authors also contacted some known IMS and invited them to let others know about this study to minimize non-response bias. Response rate could not be determined since the number of IMS who were aware of the study was unknown.

\section{Data Analysis}

Data were exported from Google Forms for data analysis using IBM SPSS v. 25. GraphPad Prism v. 9 was used to generate graphs, and MindManager v. 2018 was used to draw the coding map. Shapiro-Wilk and Kolmogorov-Smirnov normality tests were used to examine whether the data were distributed normally, which found the data set to be non-Gaussian in distribution.

Descriptive statistical analysis was performed on all the variables. Mann-Whitney $U$ tests were

Peerj reviewing PDF | (2021:05:61423:1:1:NEW 23 Jul 2021) 
199

200

201

202

203

204

205

206

207

208

209

210

211

212

213

214

215

216

217

218

219

220

221

222

223

224

225

226

227

228

229

230

231

232

233

234

235

236

237

238

used in subgroup comparisons between public and private sector and male and female IMS.

Kruskal-Wallis tests followed by Mann-Whitney U tests were used for year-wise comparisons. P values of $<0.05$ were considered statistically significant.

Content analysis, a qualitative data analysis method, was used to categorize the open text responses. The main purpose of content analysis is to capture the concepts and correlations that may explain the collected data (Şimşek \& Yıldırım, 2011). Two members of the research team coded and classified the open-ended responses separately. Then, they collectively did this based on the analysis of the core concept for each aim. To ensure authenticity, investigator triangulation was used (Ma et al., 2009). A three-step coding approach was used to further refine the analysis of responses to the open-ended question.

A thematic analysis technique was used to identify, deduce and record trends in the responses (Clarke \& Braun, 2013; Ritchie et al., 2013). A three-step coding approach was adopted (Gioia et al., 2013), similar to Strauss and Corbin's open and axial coding (1990). The first step involved coding all the open-ended responses into several codes, then axial coding (Corbin \& Strauss, 2014) was used to merge similar codes that were revealed during the first step, and cluster the codes into a less tangible form (Gioia et al., 2013). In the final step (Figure 1) all similar codes that were found in the second step were grouped into three themes; (a) IMS perception of online teaching, (b) Barriers to online teaching, and (d) Future strategies for online teaching (Gioia et al., 2013) and the frequency of the codes was calculated (Figure 2).

\section{Results}

Figure 1 About here

\section{Demographics of participants}

A total of 1107 IMS participated in this study. Among them, 750 (67.8\%) participants were males. Most $(\mathrm{n}=698 ; 63.1 \%)$ were in the age range of 21 to 23 years, followed by 24 to 26 years $(\mathrm{n}=204 ; 18.4 \%)$. The highest proportion of students were in their fourth year $(\mathrm{n}=496 ; 44.8 \%)$, followed by third year $(n=248 ; 22.4 \%)$. Students from 12 countries participated in the study, the highest proportion being from Pakistan, 297 (26.8\%), followed by Somalia 193 (17.4\%), Indonesia $132(11.9 \%)$ and India $111(10 \%)$. For most of the students ( $=1051 ; 94.9 \%)$ their current location was their home country (Table 1).

Table 1 About Here

\section{Technology readiness of the study participants and general information about online classes}

Most participants ( $\mathrm{n}=1085 ; 98 \%)$, reported easy access to the internet. However, $664(59.9 \%)$ participants rated their internet connection from poor to average, while $322(29.9 \%)$ rated the quality of their connection as excellent. More than half of the participants $(n=581 ; 52.5 \%)$, 
239

240

241

242

243

244

245

246

247

248

249

250

251

252

253

254

255

256

257

258

259

260

261

262

263

264

265

266

267

268

269

270

271

272

273

274

275

276

277

278

reported impeded electrical supply. This is an alarming situation preventing Internet connection. Smartphone $(n=642 ; 58 \%)$ and laptop $(n=310 ; 28 \%)$ were selected by most participants as the preferred devices for accessing online classes. More than half $(\mathrm{n}=587 ; 53 \%)$ of participants indicated that email was their preferred method of communication about the course schedule, followed by social media app WeChat 387 (35\%). A total of $787(71.1 \%)$ respondents reported attending three hours of online classes in a day. More than half of respondents $(n=659 ; 59.5 \%)$ reported that no assessment took place at the end of each class. A majority $(n=687 ; 62.1 \%)$ reported that three subjects were covered in a day (Table 2).

Table 2 About Here

\section{IMS experience of online classes}

Overall, students reported that online classes were not highly effective, and offered limited opportunities to interact with teachers. More than half $(n=614 ; 55.4 \%, 3.40 \pm 1.40)$ of respondents agreed or strongly agreed with the statement that online classes hamper their attention and focus. Moreover, $801(72.4 \%, 1.92 \pm 1.24)$ of the respondents disagreed or strongly disagreed that online classes are equally or more informative than campus classes. Furthermore, $664(60 \%, 1.83 \pm 1.24)$ respondents strongly disagreed that online sessions should continue even after on-campus classes have restarted (Table 3 ).

Table 3 About Here

\section{Comparison between public and private sector medical schools}

A Mann-Whitney U test was conducted to compare satisfaction with online classes among students in public and private sector medical schools. As shown in table 4, no statistically significant difference was found between IMS from public and private institutions. Students from both sectors were dissatisfied with various features of online teaching including: key information availability (Public $2.92 \pm 1.30$, Private $2.87 \pm 1.32, \mathrm{P}=0.617$ ), assistance received in overcoming difficulties (Public $3.04 \pm 1.13$, Private $2.99 \pm 1.14, \mathrm{P}=0.603$ ), teachers are well trained for online classes (Public $2.86 \pm 1.47$, Private $2.78 \pm 1.50, \mathrm{P}=0.386$ ), and whether attending classes from home hampers attention (Public $3.40 \pm 1.39$, Private $3.35 \pm 1.42$, $\mathrm{P}=0.552)$.

Table 4 About Here

\section{Effectiveness of online classes: An analysis of perceptions based on gender}

A Mann-Whitney U test was used to examine IMS perceptions of effectiveness of the online classes. Table 5 shows that IMS were dissatisfied with the effectiveness of online classes as compared with active campus learning sessions, with no significant difference in dissatisfaction between genders (male, $1.89 \pm 1.21$, female, $1.96 \pm 1.31, \mathrm{P}=0.613$ ). Similarly, no significant gender difference was found in the view that online sessions should not continue after 
279

280

281

282

283

284

285

286

287

288

289

290

291

292

293

294

295

296

297

298

299

300

301

302

303

304

305

306

307

308

309

310

311

312

313

314

315

316

317

commencement of on campus classes (Male, $1.81 \pm 1.23$, Female, $1.85 \pm 1.27, \mathrm{P}=0.785$ ). These findings indicate that IMS perceive online medical education as unhelpful in several phases of the training, such as improving their clinical skills, knowledge and discussion skills.

Table 5 About Here

\section{An analysis of perceptions based on year of study}

A Kruskal-Wallis test was used to examine IMS perceptions regarding the effectiveness of online classes. Table 6 shows that dissatisfaction with the effectiveness of online classes (based on responses to questions such as 'online learning fits in my schedules better than a typical day to day classes') was similar in all five years of study (First year $1.84 \pm 1.18$; Second year $1.81 \pm$ 1.13; Third year $1.77 \pm 1.13$; Fourth year $1.89 \pm 1.16$; Fifth year $1.93 \pm 1.22 ; \mathrm{P}=0.613$ ). These findings indicate that IMS in all phases of the program believe that online medical education is not fulfilling their needs.

Table 6 About Here

\section{IMS' perspectives on the improvement of online teaching and future strategies}

An optional open-ended question ("Please tell us the three most crucial improvements required to make online sessions more effective and anything you want to share; please feel free to share'”) was addressed by 251 (22.67\%) participants. A rigorous procedure was adopted for systematic coding. The qualitative data analysis method is described in Methods. See figure 2 for three main themes, related codes and their frequency.

Figure 2 About here

\section{Discussion}

The COVID 19 pandemic forced educational institutions worldwide to adapt and implement online platforms for teaching (Akram et al., 2021; Wu et al., 2020). Here, we discuss how this situation has shaped the use of online teaching. Some of the findings were correlated with similar challenges in different environments; it is important to remember that our results reflect students' diverse experiences from 12 countries. This investigation revealed dissatisfaction with online teaching among IMS enrolled with different medical institutions in China during the pandemic period. Previously, the courses included a rudimentary online medical education presence but the COVID-19 outbreak triggered much higher reliance on online teaching (Dost et al., 2020) and students became acquainted with various online learning methods and forums (Dhawan, 2020).

Experiences of IMS regarding the effectiveness of online teaching: Technology readiness of IMS on uptake of online teaching 
318 More than half of the respondents reported the quality of their internet connections as poor to

319 average. Poor internet connection severely impacted students' online learning experience.

320 Persistent and recurring problems of internet access have emerged as a significant challenge

321 faced by students and teachers, with previous studies reporting similar challenges to students'

322 online learning (Dridi et al., 2020). Family distractions, internet access, tutorial scheduling (Dost

323 et al., 2020) and delayed communication (Howland \& Moore, 2002; Vonderwell, 2003) are

324 significant challenges in online teaching, and may disadvantage students with limited Internet

325 access.

326 The current study also found that most students reported inadequate electrical supply during their

327 virtual classes. This is a significant observation as it has been documented that the lack of

328 sufficient electrical supply is one of the factors associated with tension among medical students, which may contribute to low academic success (Qamar et al., 2015). Our findings confirm that

330

331

332

333

334

335

336

337

338

339

340

341

342

343

344

345

346

347

348

349

350

351

352

353

354

355

356

357 electricity shortage and slow internet connections (common problems in rural areas) were perceived as leading barriers to course related information (Luqman et al., 2019). Power crises have been highlighted as contributing to reduced technology usage for access to education (Adil et al., 2020). The academic literature is mostly silent on the relationship between the power crisis and online education.

The two most critical factors limiting access to online medical education programs may be power outages and poor Internet access, affecting students' performance particularly in developing countries such as India, Tanzania, Pakistan, Somalia and others.

The present study found that respondents most commonly used smartphones to attend online classes, and the most popular means by which to receive class schedule notifications was social media (e.g., WeChat). Medical students have demonstrated positive attitudes toward learning with mobile technology (Abbasi et al., 2020; Hamilton et al., 2016; Suner et al., 2019). Time management and convenient access to information are important reasons for medical students increasingly preferring to use smartphones (Bansal et al., 2020).

\section{IMS perception of online teaching and challenges in adjusting to this new mode of learning}

Students have reportedly expressed high levels of dissatisfaction with the institutional learning management system, the online availability of teaching information, their ability to engage with teachers during online classes, and the ability to overcome obstacles to access the classes and supplementary resources (Alenezi, 2018). Several authors have indicated that virtual education systems require a robust system of hardware and software that ensures reliable access to content and resources for successful learning (Asiry, 2017; Sarwar et al., 2020).

In the present study students also expressed general disappointment with teachers' ability to offer online lectures effectively, an outcome of the need for rapid adaptation to online learning technology. This finding echoes those of other scholars who have argued that it is a demanding and time-consuming exercise to create persuasive, creative, and educational online content, and that this process requires a transitional preparation and adaptation period (Akram et al., 2021; Crawford et al., 2020; Sarwar et al., 2020) 
358

359

360

361

362

363

364

365

366

367

368

369

370

371

372

373

374

375

376

377

378

379

380

381

382

383

384

385

386

387

388

389

390

391

392

393

394

395

396

397

In the present study, students acknowledged that their concentration and focus on learning are impeded by online classes. When asked whether online classes were more informative, most students disagreed. In addition, most students disagreed that online sessions should continue after regular campus operations have been completely resumed. These findings confirm those of previous studies in which the vast majority of students in dentistry and medicine appear to prefer traditional teaching methods and learning from textbooks and lectures (Abbasi et al., 2020; Bansal et al., 2020; Sarwar et al., 2020).

In contrast, some research indicates that students favor a more comprehensive pedagogical approach. To develop students' understanding and expertise, traditional study sessions may be combined with online workshops including supplementary teaching materials and assignments (Dost et al., 2020; Hamilton et al., 2016). The development of groundbreaking educational initiatives to boost remote medical education has been initiated and may lead to success (Huddart et al., 2020).

Our findings indicate that students would like more collaborative online teaching lessons. This could be accomplished by integrating approaches such as polls, quizzes, or breakout rooms into student response systems (Dost et al., 2020; McBrien et al., 2009), to promote student engagement (Morawo et al., 2020). This active contact between teachers and students enables uncertainty to be quickly resolved to improve student engagement and build a more vibrant learning atmosphere.

\section{Future directions and practical strategies for online teaching in medical institutes}

Sufficient and updated resources contribute significantly to the online learning of students (Azevedo \& M. Marques, 2017), and their proper channelization is crucial for successful accomplishment (Akram \& Yang, 2021). IMS pointed out that compact pre-recorded videos would be helpful to learn remotely, previous research (Guo et al., 2014) indicates the same. They further emphasized that the current pandemic climate needs a collective, harmonized, and global mutual effort to create successful online pedagogy practice policies. Moreover online education in developing countries remains a relatively recent concept, and strong efforts must be made to identify successful and efficient teaching strategies to address the barriers and obstacles preventing students' access to effective online learning. Thus, the circumstances of the pandemic, lockdown and social distancing have impacted the learning of medical students.

\section{Recommendations}

The digitalization of medical teaching could play a significant role in the future of medical institutions (Dost et al., 2020). We believe that this critical student-facing issue should be addressed as soon as possible. Teachers should be encouraged to take part in online educational courses and programs that provide them with the tools they need to learn about different facets of immersive learning methods. This will help medical educators increase the effectiveness of existing online sessions. A smartphone-compatible virtual learning environment may be useful for online medical teaching. Problem-based learning or team-based learning has been found to 
398

399

400

401

402

403

404

405

406

407

408

409

410

411

412

413

414

415

416

417

418

419

420

421

422

423

424

425

426

427

428

429

430

431

432

433

434

435

436

437

improve learning outcomes (Clark, 2006; Yew \& Goh, 2016), and student motivation and understanding (Chang, 2016). There is a need for a student support system to enhance the learning environment (Aslam et al., 2020) In a lockdown environment, medical institutions must launch external resources and training initiatives such as Osmosis and BiteMedicine. Universities need to immediately sign collaboration agreements with the medical institutions within students' home countries to discuss teaching and learning arrangements for crisis periods.

\section{Strengths, limitations and future research directions}

To the researchers' knowledge, this is the first study to examine IMS' experiences of online teaching in China. The large sample size of 1107 medical students from 12 countries from both pre-clinical and clinical years is one of the study's strengths. In addition, the use of different approaches for the recruitment of medical students reduced possible bias in the responses. We studied the experiences of IMS in detail by analyzing their responses within groups based on the type of institution (public and private) as well as gender and year of study. We believe the results of our study provide important insights that will help medical institutions, educators and students to address and devise strategies to overcome the challenges to IMS learning posed by the COVID-19 pandemic.

The results may disproportionately represent views from students in some locations, with more responses from some countries (such as Pakistan) than others (such as Tanzania; Table 1), possibly introducing sampling bias. Another constraint of the study is that no assessment was made of whether institutions had trained their teachers professionally to conduct online classes, and the students' response regarding teachers' capacity to conduct classes online does not accurately reflect the teachers' ability. When IMS interactions were explored in this research, no distinctions were made between various modes of online instruction. More in-depth observational surveys, such as focus groups/ interviews/ reflection journals, should be undertaken in collaboration with medical institutions to accurately measure the impact of COVID-19 on student use of online teaching. Future researchers should investigate alternatives to clinical sessions during any crisis requiring social distancing and how to conduct and control the quality of exams.

\section{Conclusions}

This study explored the perspectives of IMS regarding the effectiveness of online teaching, challenges in adjusting to this new mode of learning and proposed practical strategies for medical institutions based on the identified factors. IMS' dissatisfaction with the various components of the online teaching indicates a need for medical institutions to enhance online learning. IMS suggested strategies including investment in faculty professional development and modification of online course content. More international collaboration may increase the quality and accessibility of online medical education. Virtual teaching, especially clinical simulation arrangements, should be developed collaboratively by advanced and developing countries, and would be helpful to IMS and assessment strategies. We recognize that COVID-19 has proven to 
438 be an extraordinary threat at the global level (Baloch et al., 2021) to which medical institutions

439 have responded, but online education needs to be developed further. It will take time and

440 experience to switch from a conventional face-to-face teaching approach to a fully functional

441 virtual education framework in the medical education field.

442

\section{Acknowledgements}

444 The authors would like to thank the Shaanxi Normal University Xian of China. The authors

445

446

447

448

449

450

451

452

453

454

455

456

457

458

459

460

461

462

463

464

465

466

467

468

469

470

471

472

473

474

475

476

477

478

479 would also like to thank all the IMS for actively taking part in this study. Special thanks to Muhammad Mussab Umair for his assistance in distributing the survey link. We would also like to express our gratitude to Prof. Dr Arshad Hasan, for his permission to use the questionnaire for this study.

\section{References}

Abbasi, S., Ayoob, T., Malik, A., \& Memon, S. I. (2020). Perceptions of students regarding Elearning during Covid-19 at a private medical college. Pakistan Journal of Medical Sciences, 36(COVID19-S4).

Adil, A., Usman, A., \& Jalil, A. (2020). Qualitative analysis of digital health literacy among university students in Pakistan. Journal of Human Behavior in the Social Environment, $1-11$.

Akram, H., Aslam, S., Saleem, A., \& Parveen, K. (2021). The Challenges of Online Teaching in COVID-19 Pandemic: A Case Study of Public Universities in Karachi, Pakistan. Journal of Information Technology Education: Research, 20, 263-282.

Akram, H., \& Yang, Y. (2021). A critical analysis of the weak implementation causes on educational policies in Pakistan. International Journal of Humanities and Innovation (IJHI), 4(1), 25-28.

Alenezi, A. (2018). Barriers to participation in learning management systems in Saudi Arabian universities. Education Research International, 2018.

Asiry, M. A. (2017). Dental students' perceptions of an online learning. The Saudi Dental Journal, 29(4), 167-170.

Aslam, S., Saleem, A., Hali, A., \& Akram, H. (2020). Science students' perceptions of the learning environment in Science degree programs. Indian Journal of Science and Technology, 13(38), 4003-4012.

Azevedo, J., \& M. Marques, M. (2017). MOOC Success Factors: Proposal of an Analysis Framework. Journal of Information Technology Education: Innovations in Practice, 16, 233-251. https://doi.org/10.28945/3861

Baloch, G. M., Sundarasen, S., Chinna, K., Nurunnabi, M., Kamaludin, K., Khoshaim, H. B., Hossain, S. F. A., \& AISukayt, A. (2021). COVID-19: Exploring impacts of the pandemic and lockdown on mental health of Pakistani students. PeerJ, 9, e10612. https://doi.org/10.7717/peerj.10612

Bansal, S., Sahadevan, D. C., Mahesh, S., Aneja, P. S., \& Aneja, M. (2020). Smartphones-Help or Hindrance in Advancing Medical/Dental Education. Journal of Evolution of Medical and Dental Sciences, 9(1), 10-14. 
480

481

482

483

484

485

486

487

488

489

490

491

492

493

494

495

496

497

498

499

500

501

502

503

504

505

506

507

508

509

510

511

512

513

514

515

516

517

518

519

520

521

522

BiteMedicine. (n.d.). BiteMedicine | Medical Knowledge Platform. Retrieved June 17, 2021, from https://www.bitemedicine.com//

Chang, B. J. (2016). Problem-based learning in medical school: A student's perspective. Annals of Medicine and Surgery, 12, 88-89.

Chen, N., Zhou, M., Dong, X., Qu, J., Gong, F., Han, Y., Qiu, Y., Wang, J., Liu, Y., \& Wei, Y. (2020). Epidemiological and clinical characteristics of 99 cases of 2019 novel coronavirus pneumonia in Wuhan, China: A descriptive study. The Lancet, 395(10223), 507-513.

Chu, Y.-X., Gao, M., Gao, H.-F., Liu, Y., Cheng, X.-J., Qian, R.-Z., Zhou, X.-F., \& Feng, Y. (2019). Current status of international medical education in China: A cross-sectional study. Traditional Medicine and Modern Medicine, 2(02), 75-84.

Clark, C. E. (2006). Problem-based learning: How do the outcomes compare with traditional teaching? British Journal of General Practice, 56(530), 722-723.

Clarke, V., \& Braun, V. (2013). Teaching thematic analysis: Overcoming challenges and developing strategies for effective learning. The Psychologist, 26(2).

Cook, D. A., Garside, S., Levinson, A. J., Dupras, D. M., \& Montori, V. M. (2010). What do we mean by web-based learning? A systematic review of the variability of interventions. Medical Education, 44(8), 765-774.

Corbin, J., \& Strauss, A. (2014). Basics of qualitative research: Techniques and procedures for developing grounded theory. Sage publications.

Crawford, J., Butler-Henderson, K., Rudolph, J., Malkawi, B., Glowatz, M., Burton, R., Magni, P., \& Lam, S. (2020). COVID-19: 20 countries' higher education intra-period digital pedagogy responses. Journal of Applied Learning \& Teaching, 3(1), 1-20.

Dhand, N. K., \& Khatkar, M. S. (2014). Statulator: An Online Statistical Calculator. Sample Size Calculator for Estimating a Single Proportion. http://statulator.com/SampleSize/ss1P.html

Dhawan, S. (2020). Online learning: A panacea in the time of COVID-19 crisis. Journal of Educational Technology Systems, 49(1), 5-22.

Dost, S., Hossain, A., Shehab, M., Abdelwahed, A., \& Al-Nusair, L. (2020). Perceptions of medical students towards online teaching during the COVID-19 pandemic: A national cross-sectional survey of 2721 UK medical students. BMJ Open, 10(11), e042378. https://doi.org/10.1136/bmjopen-2020-042378

Dridi, M. A., Radhakrishnan, D., Moser-Mercer, B., \& DeBoer, J. (2020). Challenges of Blended Learning in Refugee Camps: When Internet Connectivity Fails, Human Connection Succeeds. The International Review of Research in Open and Distributed Learning, 21(3), 250-263.

Fan, A., Kosik, R., \& Chen, Q. (2013). Internationalisation of Chinese medical schools. The Lancet, 381(9882), 1984. https://doi.org/10.1016/S0140-6736(13)61199-X

Fraenkel, J. R., Wallen, N. E., \& Hyun, H. H. (1993). How to design and evaluate research in education (Vol. 7). McGraw-hill New York.

Gioia, D. A., Corley, K. G., \& Hamilton, A. L. (2013). Seeking Qualitative Rigor in Inductive Research: Notes on the Gioia Methodology. Organizational Research Methods, 16(1), 15-31. https://doi.org/10.1177/1094428112452151

Peer) reviewing PDF | (2021:05:61423:1:1:NEW 23 Jul 2021) 
523 Gravetter, F. J., \& Forzano, L. A. B. (2011). Research methods for the behavioral sciences:

524

525

526

527

528

529

530

531

532

533

534

535

536

537

538

539

540

541

542

543

544

545

546

547

548

549

550

551

552

553

554

555

556

557

558

559

560

561

562

563

564 Cengage Learning. Stamford, CT, 147-148.

Gu, S., Li, Y., Liang, F., Feng, R., Zeng, Z., \& Wang, F. (2020). The Mediating Effects of Coping Style on the Effects of Breath Count Mindfulness Training on Depressive Symptoms among International Students in China. Neural Plasticity, 2020, 1-8. https://doi.org/10.1155/2020/8859251

Guo, P. J., Kim, J., \& Rubin, R. (2014). How video production affects student engagement: An empirical study of MOOC videos. Proceedings of the First ACM Conference on Learning@ Scale Conference, 41-50.

Hair Jr, J. F., Hult, G. T. M., Ringle, C., \& Sarstedt, M. (2016). A primer on partial least squares structural equation modeling (PLS-SEM). Sage publications.

Hamilton, L. A., Franks, A., Heidel, R. E., McDonough, S. L., \& Suda, K. J. (2016). Assessing the value of online learning and social media in pharmacy education. American Journal of Pharmaceutical Education, 80(6).

Hamutoglu, N. B., Gemikonakli, O., Duman, I., Kirksekiz, A., \& Kiyici, M. (2020). Evaluating students experiences using a virtual learning environment: Satisfaction and preferences. Educational Technology Research and Development, 68(1), 437-462.

Howland, J. L., \& Moore, J. L. (2002). Student perceptions as distance learners in Internetbased courses. Distance Education, 23(2), 183-195.

Huang, C., Wang, Y., Li, X., Ren, L., Zhao, J., Hu, Y., Zhang, L., Fan, G., Xu, J., \& Gu, X. (2020). Clinical features of patients infected with 2019 novel coronavirus in Wuhan, China. The Lancet, 395(10223), 497-506.

Huddart, D., Hirniak, J., Sethi, R., Hayer, G., Dibblin, C., Rao, B. M., Zaman, M. E., Jenkins, C., Hueso, B., \& Sethi, S. (2020). \# Med StudentCovid-How social media is supporting students during COVID-19. Medical Education.

Jianfeng, Z. (2018). The scale continues to expand, the student source structure is continuously optimized, and the attractiveness continues to increase: The work of studying in China develops towards high-level and high-quality. http://www.moe.gov.cn/jyb_xwfb/gzdt_gzdt/s5987/201803/t20180329_331772.html

Koçoglu, E., \& Tekdal, D. (2020). Analysis of Distance Education Activities Conducted during COVID-19 Pandemic. Educational Research and Reviews, 15(9), 536-543.

Krejcie, R. V., \& Morgan, D. W. (1970). Determining sample size for research activities. Educational and Psychological Measurement, 30(3), 607-610.

$\mathrm{Li}, \mathrm{G}$. X. (2019). Challenges confronted by international medical student education in China and counterplans. Qingdao: 2019 Academic Annual Conference of International Medical Student Education in China, International Medical Education Branch of China Education Association for International Exchange.

$\mathrm{Li}$, W., \& Sun, H. (2019). Migration intentions of Asian and African medical students educated in China: A cross-sectional study. Human Resources for Health, 17(1), 88.

Luqman, M., Yaseen, M., Ashraf, S., Mehmood, M. U., \& Karim, M. (2019). Factors influencing use of information and communication technologies among farmers in rural Punjab, Pakistan. Journal of Agricultural Extension, 23(2), 101-112. 
565

566

567

568

569

570

571

572

573

574

575

576

577

578

579

580

581

582

583

584

585

586

587

588

589

590

591

592

593

594

595

596

597

598

599

600

601

602

603

604

605

606

607

Ma, Y., Yin, H., Tang, L., \& Liu, L. (2009). Teacher receptivity to system-wide curriculum reform in the initiation stage: A Chinese perspective. Asia Pacific Education Review, 10(3), 423-432.

McBrien, J. L., Cheng, R., \& Jones, P. (2009). Virtual spaces: Employing a synchronous online classroom to facilitate student engagement in online learning. International Review of Research in Open and Distributed Learning, 10(3).

Morawo, A., Sun, C., \& Lowden, M. (2020). Enhancing engagement during live virtual learning using interactive quizzes. Medical Education.

Muflih, S., Abuhammad, S., Karasneh, R., Al-Azzam, S., Alzoubi, K. H., \& Muflih, M. (2020). Online Education for Undergraduate Health Professional Education during the COVID19 Pandemic: Attitudes, Barriers, and Ethical Issues.

Osmosis. (n.d.). Osmosis_Osmosis About Page. Retrieved June 17, 2021, from https://www.osmosis.org/about

Overseas Security Advisory Council. (2020). Working Together to Protect U.S. Organizations Overseas. https://www.osac.gov/Content/Report/2727c0c7-4a1c-405f-a1d9$184 c 9 b 2 c 4 d 22$

Qamar, K., Khan, N. S., \& Bashir Kiani, M. R. (2015). Factors associated with stress among medical students. J Pak Med Assoc, 65(7), 753-755.

Ritchie, J., Lewis, J., Nicholls, C. M., \& Ormston, R. (2013). Qualitative research practice: A guide for social science students and researchers. sage.

Sarwar, H., Akhtar, H., Naeem, M. M., Khan, J. A., Waraich, K., Shabbir, S., Hasan, A., \& Khurshid, Z. (2020). Self-Reported Effectiveness of e-Learning Classes during COVID19 Pandemic: A Nation-Wide Survey of Pakistani Undergraduate Dentistry Students. European Journal of Dentistry, s-0040-1717000. https://doi.org/10.1055/s-0040-1717000

Saunders, M., Lewis, P., \& Thornhill, A. (2009). Research methods for business students. Pearson education.

Şimşek, H., \& Yıldırım, A. (2011). Sosyal bilimlerde nitel araştırma yöntemleri. Ankara: Seçkin Yayıncılık.

Sindiani, A. M., Obeidat, N., Alshdaifat, E., Elsalem, L., Alwani, M. M., Rawashdeh, H., Fares, A. S., Alalawne, T., \& Tawalbeh, L. I. (2020). Distance education during the COVID-19 outbreak: A cross-sectional study among medical students in North of Jordan. Annals of Medicine and Surgery, 59, 186-194. https://doi.org/10.1016/j.amsu.2020.09.036

Suner, A., Yilmaz, Y., \& Pişkin, B. (2019). Mobile learning in dentistry: Usage habits, attitudes and perceptions of undergraduate students. PeerJ, 7, e7391.

UNESCO. (2020, March 4). 290 million students out of school due to COVID-19: UNESCO releases first global numbers and mobilizes response. UNESCO. https://en.unesco.org/news/290-million-students-out-school-due-covid-19-unescoreleases-first-global-numbers-and-mobilizes

Uttley, J. (2019). Power analysis, sample size, and assessment of statistical assumptionsImproving the evidential value of lighting research. Leukos.

Vonderwell, S. (2003). An examination of asynchronous communication experiences and perspectives of students in an online course: A case study. The Internet and Higher Education, 6(1), 77-90.

Peer] reviewing PDF | (2021:05:61423:1:1:NEW 23 Jul 2021) 
608 Wang, K., Zhang, L., \& Ye, L. (2020). A nationwide survey of online teaching strategies in dental

609

610

611

612

613

614

615

616

617

618

619

620

621

622 education in China. Journal of Dental Education, jdd.12413. https://doi.org/10.1002/jdd.12413

Wang, S., \& Dai, M. (2020). Status and situation of postgraduate medical students in China under the influence of COVID-19. Postgraduate Medical Journal, 96, 728-730. https://doi.org/10.1136/postgradmedj-2020-137763

WHO. (2020). Archived: WHO Timeline - COVID-19. https://www.who.int/news/item/27-042020-who-timeline---covid-19

Wu, D. T., Wu, K. Y., Nguyen, T. T., \& Tran, S. D. (2020). The impact of COVID-19 on dental education in North America-Where do we go next? European Journal of Dental Education: Official Journal of the Association for Dental Education in Europe, 24(4), 825-827. https://doi.org/10.1111/eje.12561

Yew, E. H., \& Goh, K. (2016). Problem-based learning: An overview of its process and impact on learning. Health Professions Education, 2(2), 75-79. 
Figure 1

\section{Representation of the coding tree that resulted from the coding process, with first-order codes, second-order codes, and aggregate themes}

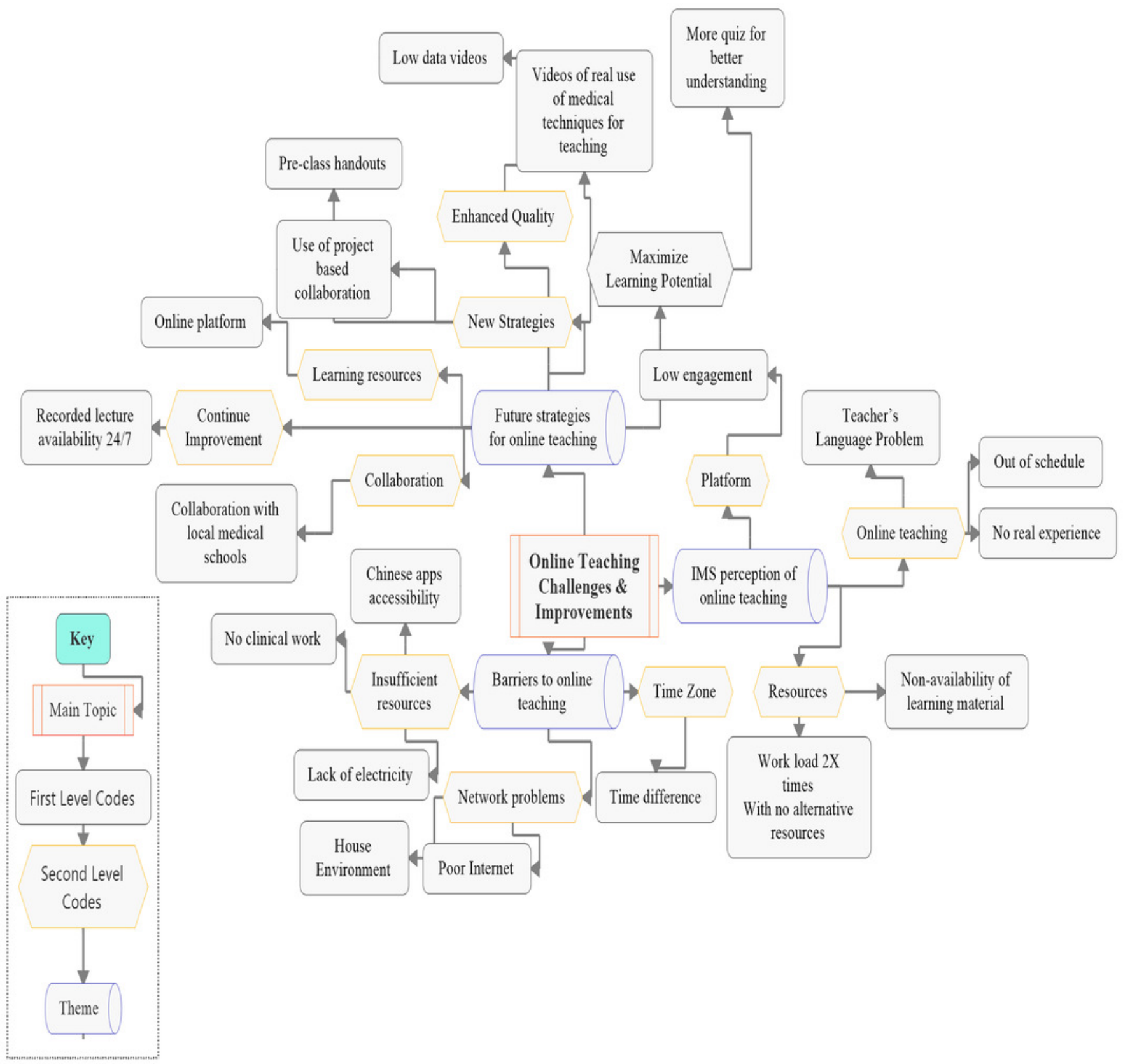


Figure 2

Representation of the coding under three aggregate themes, the indication of the number of segments retrieved per code is shown as well
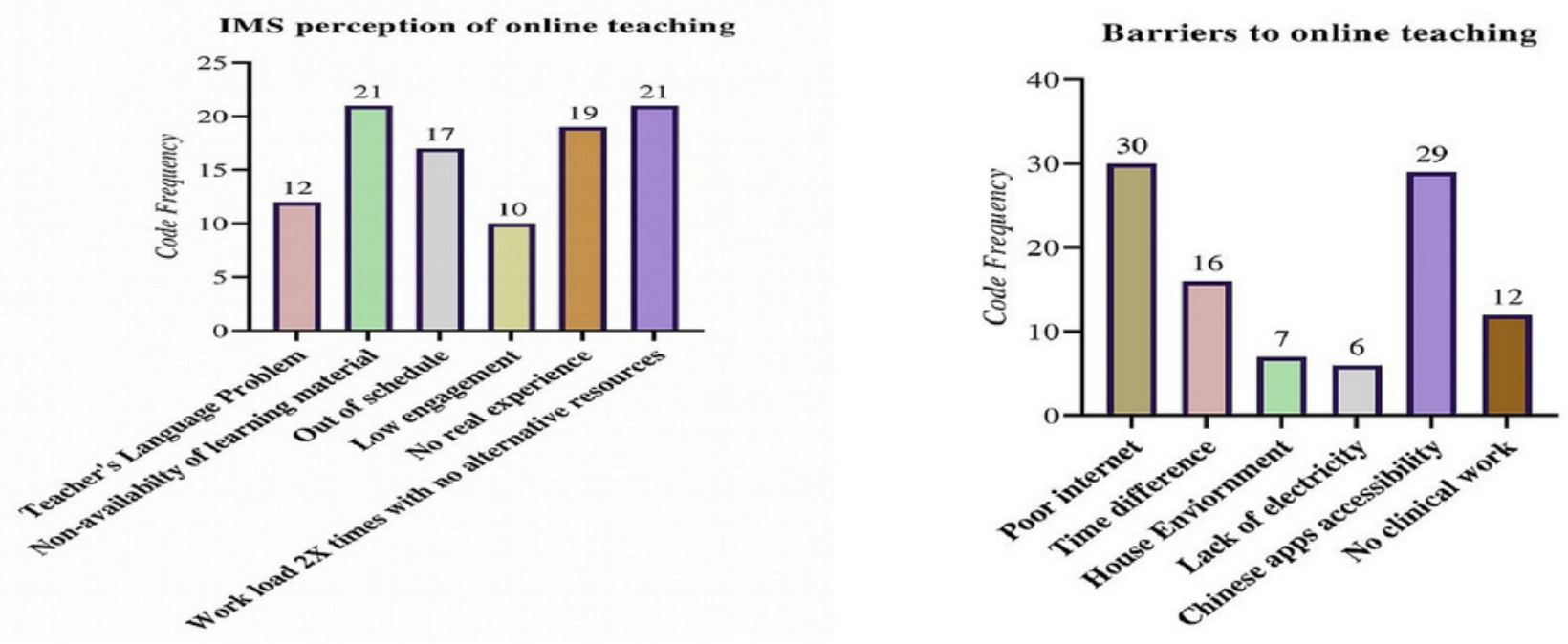

Future strategies for online teaching

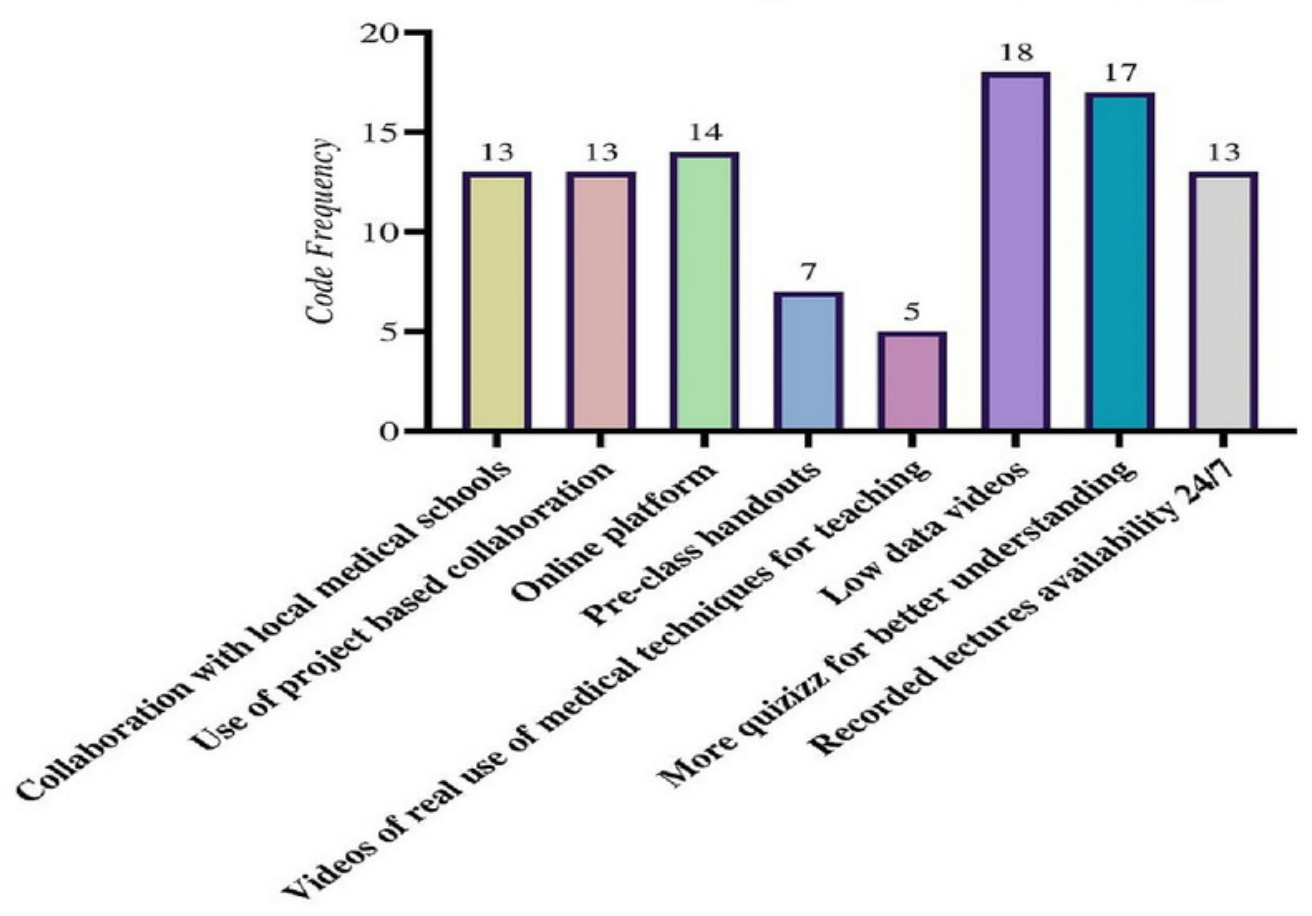




\section{Table $\mathbf{1}$ (on next page)}

A table outlining the demographics (gender, age, year of program, country of origin and current location) of IMS responding to the survey $(n=1107)$ 
1 Table 1 A table outlining the demographics (gender, age, year of program, country of

2 origin and current location) of IMS responding to the survey $(n=1107)$.

\begin{tabular}{lll}
\hline Variable & Frequency & Percentage (\%) \\
\hline Gender & 750 & \\
Male & 357 & 32.8 \\
Female & & \\
Age & 153 & 13.8 \\
18-20 years & 698 & 63.1 \\
21-23 years & 204 & 18.4 \\
24-26 years & 52 & 4.7 \\
27 \& Above & & \\
Year of Program & 113 & 10.2 \\
First-year & 125 & 11.3 \\
Second-year & 248 & 22.4 \\
Third-year & 496 & 44.8 \\
Fourth-year & 125 & 11.3 \\
Fifth-year & & \\
Country of origin & 297 & 26.8 \\
Pakistan & 193 & 17.4 \\
Somalia & 107 & 9.7 \\
Bangladesh & 132 & 11.9 \\
Indonesia & 111 & 10 \\
India & 81 & 7.3 \\
Nigeria & 51 & 4.6 \\
Sudan & 43 & 3.9 \\
Ghana & 39 & 3.5 \\
Kenya & 27 & 2.4 \\
Tanzania & 13 & 1.2 \\
Sri-Lanka & 13 & 1.2 \\
Uganda & & \\
Current location of IMS & 1051 & 94.9 \\
Home Country & 5 & 0.5 \\
Other than the home country & 51 & 4.6 \\
China & &
\end{tabular}

3 


\section{Table 2 (on next page)}

A table displaying IMS choices on their technology readiness \& information about online classes 
1 Table 2 A table displaying IMS choices on their technology readiness \& information about 2 online classes

\begin{tabular}{l} 
Statement \\
\hline Do you have easy access to the internet \\
If yes, how would you grade your internet \\
connectivity? \\
$(1=$ poor to $5=$ excellent $)$ \\
Do you have an unimpeded electrical supply? \\
Which of the following device do you use for online \\
classes
\end{tabular}

$\begin{array}{ll}\text { Poor } & 111(10 \%) \\ \text { Fair } & 333(30.1 \%) \\ \text { Average } & 220(19.9 \%) \\ \text { Good } & 121(10.9 \%) \\ \text { Excellent } & 322(29.9 \%) \\ \text { Yes } & 526(47.5 \%) \\ \text { No } & 581(52.5 \%) \\ & \\ \text { Smartphone } & \\ \text { Laptop } & 642(58 \%) \\ \text { Tablet } & 310(28 \%) \\ \text { Desktop } & 122(11 \%) \\ \text { Other } & 30(2.7 \%) \\ & 3(0.3 \%)\end{array}$

What is the mode of notification of the class schedule?

Via e-mail

$587(53 \%)$

Via social media (e.g.

WeChat, QQ)

$387(35 \%)$

Via an Institution website $133(12 \%)$

Via SMS on cell phone $\quad 00(0 \%)$

Other

$00(0 \%)$

How long before the start of a class are you informed about the lecture schedule

When did the online classes started after the 2020 vacations

$\begin{array}{ll}\text { One day before } & 365(33 \%) \\ \text { Two days before } & 609(55 \%) \\ \text { Few hours before } & 100(09 \%) \\ \text { One hour before } & 22(02 \%) \\ \text { Other } & 11(01 \%)\end{array}$

What is the duration of online teaching per day

Are you being assessed at the end of each class

$\begin{array}{ll}\text { March } & 804(72.6 \%) \\ \text { April } & 289(26.1 \%) \\ \text { May } & 14(1.3 \%) \\ \text { June } & 00(0 \%) \\ \text { August } & 00(0 \%) \\ & \\ \text { One hour } & 00(0 \%) \\ \text { Two hours } & 301(27.2 \%) \\ \text { Three hours } & 787(71.1 \%) \\ \text { Four hours } & 07(0.6 \%) \\ \text { Five or more hours } & 12(1.1 \%)\end{array}$
through a test or quiz? 
Yes

No

How many subjects are covered in one day?
$448(40.5 \%)$

$659(59.5 \%)$

$00(0 \%)$

$401(36.2 \%)$

$687(62.1 \%)$

$07(0.6 \%)$

$12(1.1 \%)$
Two

Three

Four

Five or more 


\section{Table 3(on next page)}

A table displaying students' perceptions on their experiences of online teaching, ranked on a Likert scale from 1 to 5 , where $1=$ strongly disagree and $5=$ strongly agree. Likert scores have been shown as frequency, percentage and mean \pm SD 
Table 3 A table displaying students' perceptions on their experiences of online teaching, ranked on a Likert scale from 1 to 5 , where $1=$ strongly disagree and $5=$ strongly agree. Likert scores have been shown as frequency, percentage and mean \pm SD

\begin{tabular}{|c|c|c|c|c|c|c|}
\hline Statement & $\begin{array}{l}\text { Strongly } \\
\text { agree }(n, \%)\end{array}$ & Agree (n, \%) & $\begin{array}{l}\text { Neutral (n, } \\
\%)\end{array}$ & $\begin{array}{l}\text { Disagree (n, } \\
\%)\end{array}$ & $\begin{array}{l}\text { Strongly } \\
\text { disagree (n, } \\
\%)\end{array}$ & Mean \pm SD \\
\hline $\begin{array}{l}\text { My institution has an online learning management system } \\
\text { (LMS) or Web site where all information about online classes } \\
\text { is available }\end{array}$ & $102(9.2 \%)$ & $349(31.5 \%)$ & $227(20.5 \%)$ & $238(21.5 \%)$ & $191(17.3 \%)$ & $2.93 \pm 1.25$ \\
\hline $\begin{array}{l}\text { All key information about the course is available on LMS or } \\
\text { the institution Web site }\end{array}$ & $136(12.3 \%)$ & $290(26.2 \%)$ & $221(20 \%)$ & $256(23.1 \%)$ & $204(18.4 \%)$ & $2.90 \pm 1.30$ \\
\hline $\begin{array}{l}\text { All course readings, assignments, and lectures are available } \\
\text { online }\end{array}$ & $136(12.3 \%)$ & $374(33.8 \%)$ & $221(20 \%)$ & $256(23.1 \%)$ & $120(10.8 \%)$ & $3.13 \pm 1.21$ \\
\hline $\begin{array}{l}\text { Students are assisted in overcoming obstacles in accessing the } \\
\text { classes or } \\
\text { materials }\end{array}$ & $102(9.2 \%)$ & $323(29.2 \%)$ & $290(26.2 \%)$ & $290(26.2 \%)$ & $102(9.2 \%)$ & $3.02 \pm 1.13$ \\
\hline Time allotted for online classes is sufficient & $119(10.7 \%)$ & $392(35.4 \%)$ & $205(18.5 \%)$ & $323(29.2 \%)$ & $68(6.1 \%)$ & $3.15 \pm 1.13$ \\
\hline I am able to interact with teachers during online classes & $136(12.3 \%)$ & $374(33.8 \%)$ & $153(13.8 \%)$ & $239(21.6 \%)$ & $205(18.5 \%)$ & $2.99 \pm 1.33$ \\
\hline $\begin{array}{l}\text { I am able to interact with teachers after online class in the } \\
\text { Q\&A session }\end{array}$ & $170(15.4 \%)$ & $255(23 \%)$ & $239(21.6 \%)$ & $239(21.6 \%)$ & $204(18.4 \%)$ & $2.95 \pm 1.34$ \\
\hline $\begin{array}{l}\text { Every individual is given a chance to participate and pitch in } \\
\text { their ideas during online classes }\end{array}$ & $136(12.3 \%)$ & $220(19.9 \%)$ & $256(23.1 \%)$ & $256(23.1 \%)$ & $239(21.6 \%)$ & $2.78 \pm 1.31$ \\
\hline $\begin{array}{l}\text { The teachers are well trained for online classes and are able to } \\
\text { use the Video Conferencing App with ease }\end{array}$ & $221(20 \%)$ & $170(15.4 \%)$ & $239(21.6 \%)$ & $170(15.4 \%)$ & $307(27.7 \%)$ & $2.84 \pm 1.48$ \\
\hline Attending classes from home hampers my attention and focus & $307(27.7 \%)$ & $307(27.7 \%)$ & $187(16.9 \%)$ & $136(12.3 \%)$ & $170(15.4 \%)$ & $3.40 \pm 1.40$ \\
\hline $\begin{array}{l}\text { Online classes are equally or more informative as compared } \\
\text { with active learning on campus }\end{array}$ & $68(6.1 \%)$ & $85(7.7 \%)$ & $153(13.8 \%)$ & $187(16.9 \%)$ & $614(55.5 \%)$ & $1.92 \pm 1.24$ \\
\hline $\begin{array}{l}\text { Online learning fits in my schedules better than a typical day to } \\
\text { day classes }\end{array}$ & $34(3.1 \%)$ & $102(9.2 \%)$ & $170(15.4 \%)$ & $170(15.4 \%)$ & $631(57 \%)$ & $1.86 \pm 1.16$ \\
\hline $\begin{array}{l}\text { Demonstration of Practical/ clinical/lab work by the instructor } \\
\text { during online classes would help me learn in a better way }\end{array}$ & $85(7.7 \%)$ & $120(10.8 \%)$ & $136(12.3 \%)$ & $170(15.4 \%)$ & $596(53.8 \%)$ & $2.03 \pm 1.33$ \\
\hline $\begin{array}{l}\text { I would like to have these online sessions continued even after } \\
\text { campus classes have started }\end{array}$ & $68(6.1 \%)$ & $102(9.2 \%)$ & $68(6.1 \%)$ & $205(18.5 \%)$ & $664(60 \%)$ & $1.83 \pm 1.24$ \\
\hline
\end{tabular}




\section{Table 4 (on next page)}

A Mann-Whitney $U$ test results $(p<0.05)$ : Comparison of public and private sector medical institutes regarding the effectiveness of online teaching 


\section{Table 4 A Mann-Whitney $U$ test results $(\mathbf{p}<\mathbf{0 . 0 5})$ : Comparison of public and private sector 2 medical institutes regarding the effectiveness of online teaching.}

\begin{tabular}{|c|c|c|c|}
\hline \multirow[t]{2}{*}{ Survey Questions } & \multirow{2}{*}{$\begin{array}{l}\text { Public, } \\
\mathrm{n}=806 \\
\text { Mean } \pm \mathrm{SD}\end{array}$} & $\begin{array}{l}\text { Private, } \\
n=301\end{array}$ & \multirow[t]{2}{*}{$\begin{array}{l}\text { p- } \\
\text { Value }\end{array}$} \\
\hline & & Mean \pm SD & \\
\hline $\begin{array}{l}\text { My institution has an online learning management system (LMS) or } \\
\text { Web site where all information about online classes is available }\end{array}$ & $2.95 \pm 1.25$ & $2.91 \pm 1.27$ & $0.706^{\mathrm{a}}$ \\
\hline $\begin{array}{l}\text { All key information about the course is available on LMS or the } \\
\text { institution Web site }\end{array}$ & $2.92 \pm 1.30$ & $2.87 \pm 1.32$ & $0.617^{\mathrm{a}}$ \\
\hline All course readings, assignments, and lectures are available online & $3.14 \pm 1.20$ & $3.10 \pm 1.23$ & $0.649^{\mathrm{a}}$ \\
\hline $\begin{array}{l}\text { Students are assisted in overcoming obstacles in accessing the classes or } \\
\text { materials }\end{array}$ & $3.04 \pm 1.13$ & $2.99 \pm 1.14$ & $0.603^{\mathrm{a}}$ \\
\hline Time allotted for online classes is sufficient & $3.15 \pm 1.14$ & $3.14 \pm 1.13$ & $0.941^{\mathrm{a}}$ \\
\hline I am able to interact with teachers during online classes & $2.99 \pm 1.34$ & $3.00 \pm 1.32$ & $0.950^{\mathrm{a}}$ \\
\hline I am able to interact with teachers after online class in the Q\&A session & $2.96 \pm 1.33$ & $2.91 \pm 1.34$ & $0.596^{\mathrm{a}}$ \\
\hline $\begin{array}{l}\text { Every individual is given a chance to participate and pitch in their ideas } \\
\text { during online classes }\end{array}$ & $2.80 \pm 1.31$ & $2.72 \pm 1.32$ & $0.349^{\mathrm{a}}$ \\
\hline $\begin{array}{l}\text { The teachers are well trained for online classes and are able to use the } \\
\text { Video Conferencing App with ease }\end{array}$ & $2.86 \pm 1.47$ & $2.78 \pm 1.50$ & $0.386^{\mathrm{a}}$ \\
\hline Attending classes from home hampers my attention and focus & $3.40 \pm 1.39$ & $3.35 \pm 1.42$ & $0.552^{\mathrm{a}}$ \\
\hline $\begin{array}{l}\text { Online classes are equally or more informative as compared with active } \\
\text { learning on campus }\end{array}$ & $1.92 \pm 1.24$ & $1.91 \pm 1.24$ & $0.878^{\mathrm{a}}$ \\
\hline $\begin{array}{l}\text { Online learning fits in my schedules better than a typical day to day } \\
\text { classes }\end{array}$ & $1.87 \pm 1.17$ & $1.82 \pm 1.13$ & $0.544^{\mathrm{a}}$ \\
\hline $\begin{array}{l}\text { Demonstration of Practical/ clinical/lab work by the instructor during } \\
\text { online classes would help me learn in a better way }\end{array}$ & $2.04 \pm 1.34$ & $1.99 \pm 1.31$ & $0.537^{\mathrm{a}}$ \\
\hline $\begin{array}{l}\text { I would like to have these online sessions continued even after campus } \\
\text { classes have started }\end{array}$ & $1.85 \pm 1.26$ & $1.75 \pm 1.19$ & $0.193^{\mathrm{a}}$ \\
\hline
\end{tabular}




\section{Table 5 (on next page)}

Comparison of male and female perceptions of online classes: A Mann-Whitney $U$ test results $(p<0.05)$ 


\section{Table 5 Comparison of male and female perceptions of online classes: A Mann-Whitney $\mathbf{U}$ 2 test results $(\mathbf{p}<0.05)$}

\begin{tabular}{|c|c|c|c|}
\hline \multirow[t]{2}{*}{ Survey Questions } & $\begin{array}{l}\text { Male, } \\
\mathrm{n}=750\end{array}$ & $\begin{array}{l}\text { Female, } \\
\mathrm{n}=357\end{array}$ & \multirow[t]{2}{*}{$\begin{array}{l}\text { p- } \\
\text { Value }\end{array}$} \\
\hline & Mean \pm SD & Mean \pm SD & \\
\hline $\begin{array}{l}\text { My institution has an online learning management system (LMS) or } \\
\text { Web site where all information about online classes is available }\end{array}$ & $2.92 \pm 1.28$ & $2.97 \pm 1.30$ & $0.468^{\mathrm{a}}$ \\
\hline $\begin{array}{l}\text { All key information about the course is available on LMS or the } \\
\text { institution Web site }\end{array}$ & $2.89 \pm 1.28$ & $2.93 \pm 1.36$ & $0.692^{\mathrm{a}}$ \\
\hline All course readings, assignments, and lectures are available online & $3.12 \pm 1.18$ & $3.15 \pm 1.26$ & $0.587^{\mathrm{a}}$ \\
\hline $\begin{array}{l}\text { Students are assisted in overcoming obstacles in accessing the classes or } \\
\text { materials }\end{array}$ & $3.01 \pm 1.123$ & $3.06 \pm 1.15$ & $0.565^{\mathrm{a}}$ \\
\hline Time allotted for online classes is sufficient & $3.14 \pm 1.11$ & $3.17 \pm 1.19$ & $0.719^{\mathrm{a}}$ \\
\hline I am able to interact with teachers during online classes & $2.97 \pm 1.32$ & $3.04 \pm 1.37$ & $0.401^{\mathrm{a}}$ \\
\hline I am able to interact with teachers after online class in the Q\&A session & $2.93 \pm 1.32$ & $2.98 \pm 1.38$ & $0.561^{\mathrm{a}}$ \\
\hline $\begin{array}{l}\text { Every individual is given a chance to participate and pitch in their ideas } \\
\text { during online classes }\end{array}$ & $2.77 \pm 1.28$ & $2.79 \pm 1.38$ & $0.895^{\mathrm{a}}$ \\
\hline $\begin{array}{l}\text { The teachers are well trained for online classes and are able to use the } \\
\text { Video Conferencing App with ease }\end{array}$ & $2.82 \pm 1.45$ & $2.87 \pm 1.52$ & $0.624^{\mathrm{a}}$ \\
\hline Attending classes from home hampers my attention and focus & $3.38 \pm 1.38$ & $3.43 \pm 1.44$ & $0.402^{\mathrm{a}}$ \\
\hline $\begin{array}{l}\text { Online classes are equally or more informative as compared with active } \\
\text { learning on campus }\end{array}$ & $1.89 \pm 1.21$ & $1.96 \pm 1.31$ & $0.613^{a}$ \\
\hline $\begin{array}{l}\text { Online learning fits in my schedules better than a typical day to day } \\
\text { classes }\end{array}$ & $1.84 \pm 1.13$ & $1.88 \pm 1.21$ & $0.837^{\mathrm{a}}$ \\
\hline $\begin{array}{l}\text { Demonstration of Practical/ clinical/lab work by the instructor during } \\
\text { online classes would help me learn in a better way }\end{array}$ & $1.98 \pm 1.29$ & $2.12 \pm 1.42$ & $0.254^{\mathrm{a}}$ \\
\hline I would like to have these online sessions continued even after campus & $1.81 \pm 1.23$ & $1.85 \pm 1.27$ & $0.785^{\mathrm{a}}$ \\
\hline
\end{tabular}


Table 6(on next page)

A Kruskal-Wallis test results $(p<0.05)$ : Year-wise comparison of IMS perceptions of online classes 
1 Table 6 A Kruskal-Wallis test results $(\mathbf{p}<0.05)$ : Year-wise comparison of IMS perceptions of online classes

\begin{tabular}{|c|c|c|c|c|c|c|}
\hline Survey Questions & $\begin{array}{l}\text { First year, } \\
\mathrm{n}=113 \\
\text { Mean } \pm \text { SD }\end{array}$ & $\begin{array}{l}\begin{array}{l}\text { Second } \\
\text { year, } \\
\mathrm{n}=125 \\
\text { Mean } \pm \mathrm{SD}\end{array}\end{array}$ & $\begin{array}{l}\text { Third year, } \\
\mathrm{n}=248 \\
\text { Mean } \pm \mathrm{SD}\end{array}$ & $\begin{array}{l}\text { Fourth } \\
\text { year, } \\
\mathrm{n}=496 \\
\text { Mean } \pm \mathrm{SD}\end{array}$ & $\begin{array}{l}\text { Fifth year, } \\
\mathrm{n}=125 \\
\text { Mean } \pm \text { SD }\end{array}$ & $\begin{array}{l}\text { p- } \\
\text { Value }\end{array}$ \\
\hline $\begin{array}{l}\text { My institution has an online learning management system (LMS) or } \\
\text { Web site where all information about online classes is available }\end{array}$ & $2.90 \pm 1.26$ & $2.85 \pm 1.28$ & $2.97 \pm 1.24$ & $2.93 \pm 1.26$ & $2.98 \pm 1.28$ & $0.882^{\mathrm{a}}$ \\
\hline $\begin{array}{l}\text { All key information about the course is available on LMS or the } \\
\text { institution Web site }\end{array}$ & $2.87 \pm 1.33$ & $2.83 \pm 1.34$ & $2.94 \pm 1.30$ & $2.90 \pm 1.29$ & $2.96 \pm 1.32$ & $0.915^{\mathrm{a}}$ \\
\hline All course readings, assignments, and lectures are available online & $3.11 \pm 1.24$ & $3.09 \pm 1.25$ & $3.14 \pm 1.22$ & $3.14 \pm 1.19$ & $3.15 \pm 1.24$ & $0.996^{\mathrm{a}}$ \\
\hline $\begin{array}{l}\text { Students are assisted in overcoming obstacles in accessing the classes or } \\
\text { materials }\end{array}$ & $2.95 \pm 1.18$ & $2.96 \pm 1.18$ & $3.08 \pm 1.16$ & $3.03 \pm 1.10$ & $3.05 \pm 1.12$ & $0.812^{\mathrm{a}}$ \\
\hline Time allotted for online classes is sufficient & $3.13 \pm 1.16$ & $3.11 \pm 1.18$ & $3.15 \pm 1.12$ & $3.16 \pm 1.13$ & $3.16 \pm 1.15$ & $0.994^{\mathrm{a}}$ \\
\hline I am able to interact with teachers during online classes & $3.03 \pm 1.31$ & $2.96 \pm 1.36$ & $2.99 \pm 1.35$ & $3.00 \pm 1.31$ & $2.96 \pm 1.40$ & $0.995^{\mathrm{a}}$ \\
\hline I am able to interact with teachers after online class in the Q\&A session & $2.99 \pm 1.36$ & $2.97 \pm 1.35$ & $2.89 \pm 1.36$ & $2.95 \pm 1.31$ & $2.99 \pm 1.37$ & $0.946^{\mathrm{a}}$ \\
\hline $\begin{array}{l}\text { Every individual is given a chance to participate and pitch in their ideas } \\
\text { during online classes }\end{array}$ & $2.72 \pm 1.33$ & $2.69 \pm 1.34$ & $2.74 \pm 1.34$ & $2.81 \pm 1.29$ & $2.85 \pm 1.33$ & $0.759^{\mathrm{a}}$ \\
\hline $\begin{array}{l}\text { The teachers are well trained for online classes and are able to use the } \\
\text { Video Conferencing App with ease }\end{array}$ & $2.97 \pm 1.46$ & $2.85 \pm 1.52$ & $2.76 \pm 1.52$ & $2.84 \pm 1.44$ & $2.85 \pm 1.50$ & $0.793^{\mathrm{a}}$ \\
\hline Attending classes from home hampers my attention and focus & $3.38 \pm 1.38$ & $3.46 \pm 1.50$ & $3.34 \pm 1.39$ & $3.41 \pm 1.38$ & $3.43 \pm 1.38$ & $0.854^{a}$ \\
\hline $\begin{array}{l}\text { Online classes are equally or more informative as compared with active } \\
\text { learning on campus }\end{array}$ & $1.88 \pm 1.24$ & $1.85 \pm 1.21$ & $1.84 \pm 1.21$ & $1.97 \pm 1.25$ & $1.96 \pm 1.28$ & $0.579^{a}$ \\
\hline $\begin{array}{l}\text { Online learning fits in my schedules better than a typical day to day } \\
\text { classes }\end{array}$ & $1.84 \pm 1.18$ & $1.81 \pm 1.13$ & $1.77 \pm 1.13$ & $1.89 \pm 1.16$ & $1.93 \pm 1.22$ & $0.621^{\mathrm{a}}$ \\
\hline $\begin{array}{l}\text { Demonstration of Practical/ clinical/lab work by the instructor during } \\
\text { online classes would help me learn in a better way }\end{array}$ & $2.00 \pm 1.35$ & $1.98 \pm 1.33$ & $1.95 \pm 1.32$ & $2.08 \pm 1.33$ & $2.05 \pm 1.35$ & $0.647^{\mathrm{a}}$ \\
\hline $\begin{array}{l}\text { I would like to have these online sessions continued even after campus } \\
\text { classes have started }\end{array}$ & $1.77 \pm 1.23$ & $1.79 \pm 1.20$ & $1.87 \pm 1.26$ & $1.82 \pm 1.25$ & $1.84 \pm 1.26$ & $0.930^{\mathrm{a}}$ \\
\hline
\end{tabular}

$\mathrm{SD}=$ standard deviation, ${ }^{\mathrm{a}} \mathrm{p}$-Value calculated by using Kruskal-Wallis test 